\title{
COMPARATIVE ANALYSIS OF THE ESSENTIAL OILS OF THREE LAMIACEAE SPECIES OBTAINED BY CONVENTIONAL AND MICROWAVE-ASSISTED HYDRODISTILLATION
}

\section{KOMPARATIVNA ANALIZA ETARSKIH ULJA TRI LAMIACEAE VRSTE DOBIJENIH KONVENCIONALNOM I MIKROTALASNOM DESTILACIJOM}

\author{
Branimir PAVLIĆ*, Dejan SAVIĆ**, Jelena VLADIĆ*, Senka VIDOVIĆ*, Zoran ZEKOVIĆ* \\ *University of Novi Sad, Faculty of Technology, 21000 Novi Sad, Bulevar cara Lazara 1, Serbia \\ ** DSP Chromatography, 11000 Belgrade, Bulevar Milutina Milankovića 120g, Serbia \\ e-mail: zzekovic@tf.uns.ac.rs
}

\begin{abstract}
The purpose of this paper is to compare the essential oils (EOs) of three Lamiaceae species (Satureja montana (winter savory), Ocimum basilicum (basil) and Origanum vulgare (oregano)) isolated by hydrodistillation (HD) and microwave-assisted hydrodistillation (MWHD). The total EO yields of all three plants obtained by MWHD were nearly twofold lower than those obtained by HD. However, the microwave treatment was found to be significantly shorter. The chemical profile of the EOs obtained was determined using GC-MS. Carvacrol was the most abundant compound in the winter savory and oregano EOs (92.20 and $93.42 \%$, respectively), whereas linalool was the predominant compound in the basil EO (67.71\%). The results obtained indicate that certain chemical alterations occur during microwave treatments. The MWHD of winter savory led to a decrease in the carvacrol content (84.11\%), accompanied by a significant increase in the antioxidant activity determined by the DPPH assay, compared to the winter savory EO obtained by HD. Although a decrease in major compound contents of both the basil and oregano EOs obtained by MWHD was observed, no significant difference was found in their antioxidant activity.
\end{abstract}

Keywords: Lamiaceae, hydrodistillation, microwave-assisted hydrodistillation, essential oil.

\section{REZIME}

У овом раду су етарска уља (EOs) из три Lamiaceae вpcme (Satureja montana - rtanjski čaj, Ocimum basilicum - bosiljak u Origanum vulgare - origano) изолована коришћењем хидродестилације (HD) и микроталасне хидродестилације (MWHD). Mikrotalasna destilacija vodom je uvedena kao alternativa tradicionalnoj destilaciji vodom za izolovanje etarskog ulja, u cilju poboljšanja procesa u pogledu smanjenja vremena destilacije, poboljšanja kvaliteta i prinosa etarskog ulja. Укynaн npuнос EO добијених поступком MWHD је био скоро дупло нижи у поређењу са HD, међутим, третман микроталасима је био значајно краћи (10 min). Хемијски профил добијених EOs је одређен GC-MS техником i definisan je relativni udeo glavnih јеdinjenja u ispitivanim иzогсіта. Карвакрол је био најзаступљеније једињене у етарском уљу ртањског чаја и оригана (92.20 и $93.42 \%$, респективно), док је линалоол био најдоминантније једињење у етарском уљу босиљка (67.71\%). Резултати су показали да током микроталасног третмана долази до одређених хемијских промена. MWHD ртањског чаја је у поређењу са HD је била праћена смањењем садржаја карвакрола (84.11\%), уз повећање антиоксидативне активности одређене DРPH тестом. Иако је у EOs босиљка и оригана добијених MWHD дошло до смањења садржаја главних компонената, није било значајне промене у антиоксидативној активности. Rezultati su pokazali da upotreba mikrotalasa može da se koristi za intenzifikaciju hidrodestilacije, međutim neophodno je izvršiti dalja ispitivanja u cilju optimizacije procesa.

Ključne reči: Lamiaceae, хидродестилачија, микроталасна дестилација, етарско уље.

\section{INTRODUCTION}

Essential oils (EOs) are complex mixtures of secondary plant metabolites widely applied in the food and pharmaceutical industry. As they are used in different industries, it is necessary to find the best extraction procedure, resulting in products of high quality and satisfying yields (Hashemi-Moghaddam et al., 2013). Hydrodistillation (HD) and solvent extraction are the most frequently used procedures for the EO isolation. Solvent extraction with commonly used organic solvents such as methylene chloride and hexane usually provides high yields of EO. However, this technique has a number of disadvantages due to the toxicity of organic solvents, the huge time consumption and the retention of solvent traces in final products (Mohamadi et al., 2013). Moreover, organic solvent consumption exerts a negative impact on the environment. HD is a procedure suitable for the isolation of non-water soluble, high-boiling point compounds such as EOs (Binello et al., 2014). Although a method of choice, HD can cause chemical alterations of EO constituents such as hydrolysis and degradation. Therefore, alternative procedures should be considered. Supercritical fluid extraction (SFE) with carbon dioxide has been recognized as a favorable alternative to conventional techniques in the EO isolation. In addition to relatively mild critical parameters $\left(\mathrm{T}_{\mathrm{c}}=\right.$ $32{ }^{\circ} \mathrm{C}$ and $\mathrm{p}_{\mathrm{c}}=74$ bar), carbon dioxide has other advantages as it is non-toxic, non-flammable, available in high purity at a relatively low cost and is easily removed from extracts, providing quality solvent-free extracts (Pourmortazavi and Hajimirsadeghi, 2007). Moreover, SFE is highly convenient as the selectivity of the solvent depends on the solvent temperature and pressure, i.e. solvent density which could be easily modified and adapted. EOs are commonly extracted at $40{ }^{\circ} \mathrm{C}$ and 100 bar, i.e. a solvent density of $0.629 \mathrm{~g} / \mathrm{cm}^{3}$, as these conditions prevent the coextraction of cuticular waxes and other non-polar compounds (Reverchon, 1997; Pourmortazavi and Hajimirsadeghi, 2007). 
Another approach is the modification and upgrade of standard procedures, i.e. hydrodistillation and extraction, through the application of ultrasonic, microwave and highpressure treatments. Therefore, microwave-assisted hydrodistillation (MWHD) was successfully developed for the laboratory-scale EO isolation (Wang et al., 2009; Feng et al., 2010; Jiang et al., 2013). MWHD has been recognized as a "green" technique, developed to reduce the distillation time, enhance the quality of EOs and potentially improve the yield (Golmakani et al., 2008). The most important advantage of this technique is the effective heat transfer through microwave irradiation. Moreover, it provides a faster response to the process heating control, a faster start-up and a significant reduction in time consumption (Wang et al., 2012). Time is directly connected with the economic aspect of each process. Therefore, its decrease can often result in increased efficiency and costs. Moreover, minimizing treatments under harsh conditions, e.g. increased temperature, could potentially lead to high-quality products with increased biological activity.

Lamiaceae is considered as one of the richest families of medicinal plants (Nikolić and Rešetnik, 2007). Lamiaceae species have been reported to possess a vast range of biological activities and a wide diversity of phytochemicals. EOs, hydroxycinnamic acids and flavonoids are the major bioactive constituents of the most common Lamiaceae species such as thyme, basil, winter savory, rosemary, peppermint, sage, lemon balm and oregano (Štefan et al., 2014). The purpose of this paper is to compare the HD and MWHD of the EOs from three Lamiaceae species (Satureja montana, Ocimum basilicum and Origanum vulgare). The EOs obtained were compared relative to the yield, chemical profile and antioxidant activity.

\section{MATERIAL AND METHOD}

Plant material

The sweet basil (Ocimum basilicum L.) and winter savory (Satureja montana L.) plants used were produced by the Institute of Field and Vegetable Crops, Novi Sad, Serbia, in 2012. The plant material collected was air-dried and stored at room temperature. Oregano (Origanum vulgare L.) was purchased at a local market. The dried plant materials were separately milled using a common blender (CNSM10 Bosch, Germany). Subsequently, mean particle sizes of sweet basil, winter savory and oregano $(0.215 \mathrm{~mm}, 0.351 \mathrm{~mm}$ and $0.224 \mathrm{~mm}$, respectively) were determined using a sieve (CISA Cedaceria Industrial, Spain). A total of $200 \mathrm{~g}$ of plant material was ground for $10 \mathrm{~s}$, collected and stored in sealed plastic bags. The mean particle size was determined by sieving $100 \mathrm{~g}$ of plant material under the following conditions: a sieving time of $30 \mathrm{~min}$, cycles: $9 \mathrm{~s}$ on and $1 \mathrm{~s}$ off, and an amplitude of $1 \mathrm{~mm}$.

Chemicals

1,1-Diphenyl-2-picryl-hydrazyl-hydrate (DPPH) was purchased from Sigma (Sigma-Aldrich GmbH, Sternheim, Germany). All other chemicals and reagents were of analytical reagent grade.

Hydrodistillation

The EO content was determined using the official Ph. Jug. IV procedure (Ph. Jug. IV). The dried plant material (20.0 g) was placed in a rounded glass flask, and $400 \mathrm{~mL}$ of distilled water was added. Distillation was performed in an all-glass Clevenger apparatus for 2 hours. Essential oils were collected and stored at $4{ }^{\circ} \mathrm{C}$ to prevent any possible degradation until the analysis. All the experiments were performed in triplicate.

Microwave-assisted hydrodistillation (MWHD)
For this purpose, a microwave oven (NN-E201W, Panasonic, Japan) was modified with an appropriate glass apparatus (Figure $1)$. The Dried plant material (20.0 g) was placed in a rounded glass flask (4), and $400 \mathrm{~mL}$ of distilled water was added. Microwave-assisted hydrodistillation was performed in the oven (1). All the runs were performed at an irradiation power of 470 W for 10 minutes, which was regulated using an irradiation power controller (2) and a time controller (4). Water-oil mixture evaporated through a glass pipe connector (5) to be condensed in the Clevenger apparatus used for standard hydrodistillation (6). As the condenser within the Clevenger apparatus could not provide enough heat exchanging surface area to condense the entire vapor, an additional condenser (7) was added to prevent any possible EO losses. The essential oils obtained were collected and stored at $4{ }^{\circ} \mathrm{C}$ to prevent any possible degradation until the analysis. All the experiments were performed in triplicate.

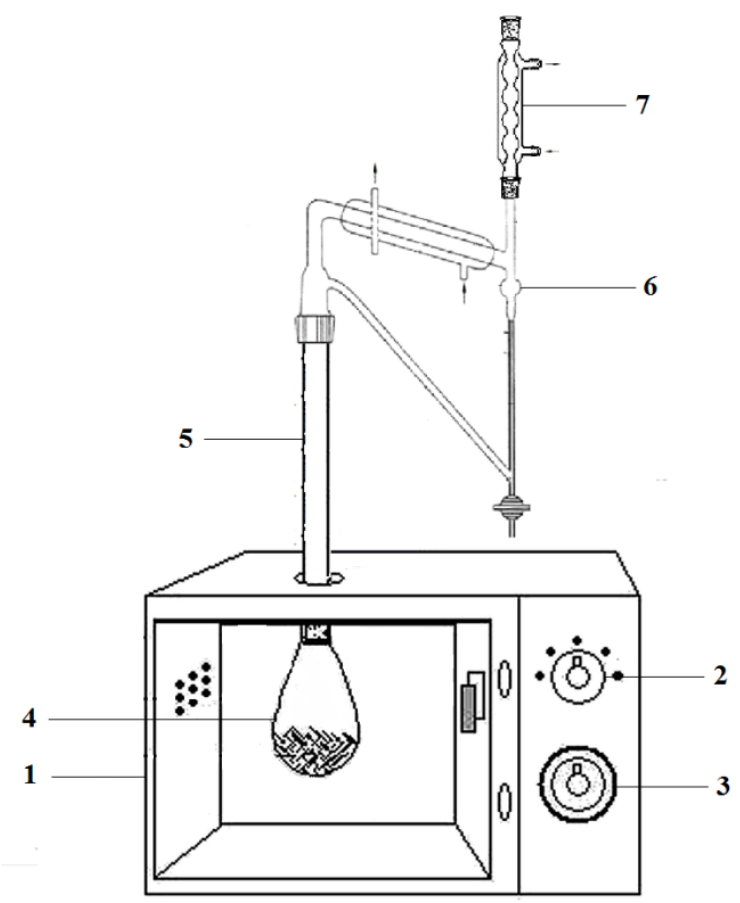

Fig 1. Schematic diagram of the microwave-assisted distillation apparatus: 1. microwave oven, 2. irradiation power controller, 3. time controller, 4. glass flask, 5. glass pipe connector, 6 . Clevenger apparatus, and 7. condenser

Thin-layer chromatography (TLC)

For TLC, EO solutions in toluene $(1: 40 ; \mathrm{v} / \mathrm{v})$ were prepared. Glass plates $(20 \times 10 \mathrm{~cm})$ were coated in our laboratory using Silica Gel G (Merck, Germany) with a thickness of $0.25 \mathrm{~mm}$. Solutions were applied on the plates in different volumes $(2,4$, 8, 12 and $16 \mu \mathrm{l}$ ) using a semi-automatic applicator (Linomat 5, Camag, Switzerland) with $2 \mathrm{~nL} / \mathrm{s}$ flow. The mobile phase for the development was toluene: ethylacetate $(93: 7 ; \mathrm{v} / \mathrm{v})$. The plates were developed in an automatic developing chamber (ADC2, Camag, Switzerland), at room temperature (approx. $20^{\circ} \mathrm{C}$ ) and $75 \%$ relative humidity. The glass chamber was saturated with a $20 \mathrm{~mL}$ mobile phase for 15 min before development. Detection was performed by spraying the plates developed with $1 \%$ vanillin reagent ( $1 \mathrm{~g}$ of vanillin was dissolved in $99 \mathrm{~g}$ mixture of $95 \%$ ethanol and cc. sulfuric acid, a ratio of 9:1; w/w). After spraying, the plates were heated at $110^{\circ} \mathrm{C}$ for $5-10 \mathrm{~min}$ (Wagner et al., 1984).

Gas chromatography - mass spectrometry (GC-MS) 
The GC-MS analysis was performed using the Hewlett Packard GC 5890 series II system, coupled to the mass Hewlett Packard 5971 spectrometer. The HP-5MS column (30 m length, $0.25 \mathrm{~mm}$ inner diameter and $0.25 \mu \mathrm{m}$ film thickness) was used. The helium flow rate was $2 \mathrm{~mL} / \mathrm{min}$. The EO samples obtained were dissolved in methylene chloride $(1: 10 ; \mathrm{v} / \mathrm{v})$ and the injected volume of solution was $5 \mu \mathrm{L}$ with a split ratio of $30: 1$. The experimental temperature conditions were as follows: an injector temperature of $250{ }^{\circ} \mathrm{C}$, a detector temperature of $300{ }^{\circ} \mathrm{C}$; an initial temperature of $60{ }^{\circ} \mathrm{C}$ with a linear increase of $4{ }^{\circ} \mathrm{C} / \mathrm{min}$ to $150{ }^{\circ} \mathrm{C}$. A final hold for $3 \mathrm{~min}$ was allowed for a complete column clean-up. EO compounds were identified by comparing their mass spectral data and retention times with those from the NIST 05 and Wiley $7 \mathrm{n}$ data base. For each compound on the chromatogram, the percentage of peak area relative to the total peak areas of all the compounds was determined, and expressed as a relative amount of the compound (\%).

Antioxidant activity

Free radical scavenging activity of EOs was determined using the DPPH assay, previously described by Espín et al. (2000). A certain volume of diluted EO sample was mixed with $95 \%$ methanol and $90 \mu \mathrm{M}$ 1,1-diphenyl-2-picryl-hydrazyl (DPPH) in order to obtain different final concentrations. After incubation at room temperature for $60 \mathrm{~min}$, the absorbance was measured at $515 \mathrm{~nm}$, and the results obtained were expressed as the radical scavenging capacity (RSC, \%) which was calculated using the following equation:

$$
\% R S C=100-\frac{\left(A_{\text {sample }} \times 100\right)}{A_{\text {blank }}}
$$

where $A_{\text {sample }}$ is the absorbance of sample solution and $A_{\text {blank }}$ is the absorbance of blank probe. Antioxidant activity was further expressed as the inhibition concentration at $50 \%$ of the RSC value $\left(\mathrm{IC}_{50}\right) . \mathrm{IC}_{50}$ represents the concentration of the test solution required to obtain $50 \%$ of the radical scavenging capacity.

\section{RESULTS AND DISCUSSION}

The yields of essential oils (EOs) obtained by the two examined procedures are presented in Table 1. Hydrodistillation (HD) produced the highest yield of $O$. vulgare EO (3.00\%), whereas the $O$. basilicum EO yield obtained by microwaveassisted hydrodistillation (MWHD) was the lowest (0.31 \%). There was a significant difference in the EO yield obtained by HD and MWHD, as HD produced approximately a twofold higher yield than MWHD. This can be accounted for by a relatively short period of microwave treatment $(10 \mathrm{~min})$ at 470 $\mathrm{W}$, which was applied in order to minimize and prevent possible chemical alterations during prolonged microwave treatments. Moreover, an additional condenser was added to the MWHD apparatus (Figure 1) in order to prevent possible EO losses due to intensive evaporation caused by microwave irradiation. Binello et al. (2014) did not observe any significant difference in the EO yield of $O$. vulgare and $O$. basilicum obtained by HD and MWHD for 20 min, which indicates that the MWHD process should be prolonged in order to ensure a complete extraction of EOs.

Table 1. Yield of the essential oils obtained by hydrodistillation and microwave-assisted hydrodistillation

\begin{tabular}{||l|c|c||}
\hline \multirow{2}{*}{ Plant material } & \multicolumn{2}{|c||}{ Essential oil yield [\%, v/m] } \\
\cline { 2 - 3 } & HD & MWHD \\
\hline Satureja montana & 1.10 & 0.58 \\
\hline Ocimum basilicum & 0.73 & 0.31 \\
\hline Origanum vulgare & 3.00 & 1.45 \\
\hline
\end{tabular}

Thin-layer chromatography (TLC) was used for a fingerprint analysis of the EOs obtained in order to provide the information about differences in the chemical profile of EOs obtained by HD and MWHD. After chromatographic separation, the TLC plates were sprayed with a vanillin reagent and heated in order to visualize spots on the plates (Figure 2). $R_{f}$ values were determined and compared to those from the literature. The Satureja montana EOs obtained by HD and MWHD were separated as shown in Figure $2 \mathrm{~A}$ and $2 \mathrm{~B}$, respectively. It has been previously reported that carvacrol is the predominant constituent (> $50 \%$ ) of the S. montana EO (Panizzi et al., 1993). According to the literature, the red spot at $0.50-0.55 \mathrm{R}_{\mathrm{f}}$ belongs to thymol-carvacrol mixture (Wagner et al., 1984). This spot had an approximate $\mathrm{R}_{\mathrm{f}}(0.49)$ on the developed plates of the $S$. montana EO obtained by both HD and MWHD (Figure 2A and 2B). However, as the thymol content was found to be significantly lower, the spot could be attributed only to carvacrol. There were no significant differences between the $S$. montana EOs obtained by HD and MWHD as all the spots were similarly positioned and colored. The EOs of Ocimum basilicum obtained by MWHD and HD were separated as shown in Figure 2C and 2D, respectively. Only three compounds were identified at $0.18,0.31$ and $0.45 \mathrm{R}_{\mathrm{f}}$ in the EO obtained by HD. According to the literature, the compounds identified at $\mathrm{R}_{\mathrm{f}} 0.31$ and 0.45 are linalool and eugenol, respectively (Wagner et al., 1984) (which was rather expected since linalool is the most abundant compound in the basil EO (Filip et al., 2014)). Conversely, the chromatogram of the basil EO obtained by MWHD showed three additional spots at $\mathrm{R}_{\mathrm{f}} 0.46,0.48$ and 0.75 , which could indicate that microwave irradiation caused chemical alterations of the EO. In the case of the Origanum vulgare EO, the chromatograms of EOs obtained by HD and MWHD were similar (Figure 2E and 2F). The same compounds were identified in both EOs at $\mathrm{R}_{\mathrm{f}} 0.12,0.21,0.30,0.48$, and 0.78, respectively. According to Kulisic et al. (2004), thymol and carvacrol are the predominant compounds in the oregano essential oil, which was confirmed by TLC as red spots occurred on the chromatograms of the EOs obtained by both HD and MWHD. The compounds at $R_{f} 0.12,0.21$ and 0.30 were found to be terpene alcohols (borneol, geraniol and linalool, respectively). A TLC finger-print analysis proved useful for qualitative analysis. However, in order to provide additional information about possible chemical alterations and differences between the EOs obtained by HD and MWHD, a more sophisticated chromatographic analysis, i.e. the gas chromatography-mass spectrometry, should be applied.

A detailed chemical composition of the three investigated EOs determined by GC-MS is presented in Table 2. On balance, the EOs of winter savory, basil and oregano had an approximate number of identified volatiles. However, certain differences in their relative percentage were observed. Only oxygenated monoterpenes, i.e. linalool and thymol, were identified in all the EOs. Carvacrol was the most abundant compound in the $S$. montana EO obtained by HD and MWHD (92.20 and $84.11 \%$, respectively), which is in accordance with previous reports (Milos et al., 2001). However, a certain decrease in the carvacrol content was observed in the EO obtained by MWHD, probably because of a short distillation time (10 min). Both EOs were rich in oxygenated monotepenes, whereas a slight increase in linalool, borneol, $\alpha$-terpineol, thymoquinone and thymol was observed in the EO obtained by MWHD. This could indicate that microwave irradiation causes chemical alterations of carvacrol, 
which potentially transforms to other oxygenated compounds. Compared to other carvacrol-rich plants, a slight decrease in the carvacrol content was observed in the MWHD of Zataria multiflora EO (Golmakani and Rezaei, 2008), whereas its content was very similar to that found in the EOs of Thymus vulgaris obtained by the same techniques (Golmakani et al., 2008). In addition to the reduction of the carvacrol content, a significant content of unidentified compounds $(\mathrm{RT}=28.45 \mathrm{~min}$ ) was observed in the $S$. montana EO obtained only by MWHD (7.29\%), which could be identified as a potential product of carvacrol degradation.
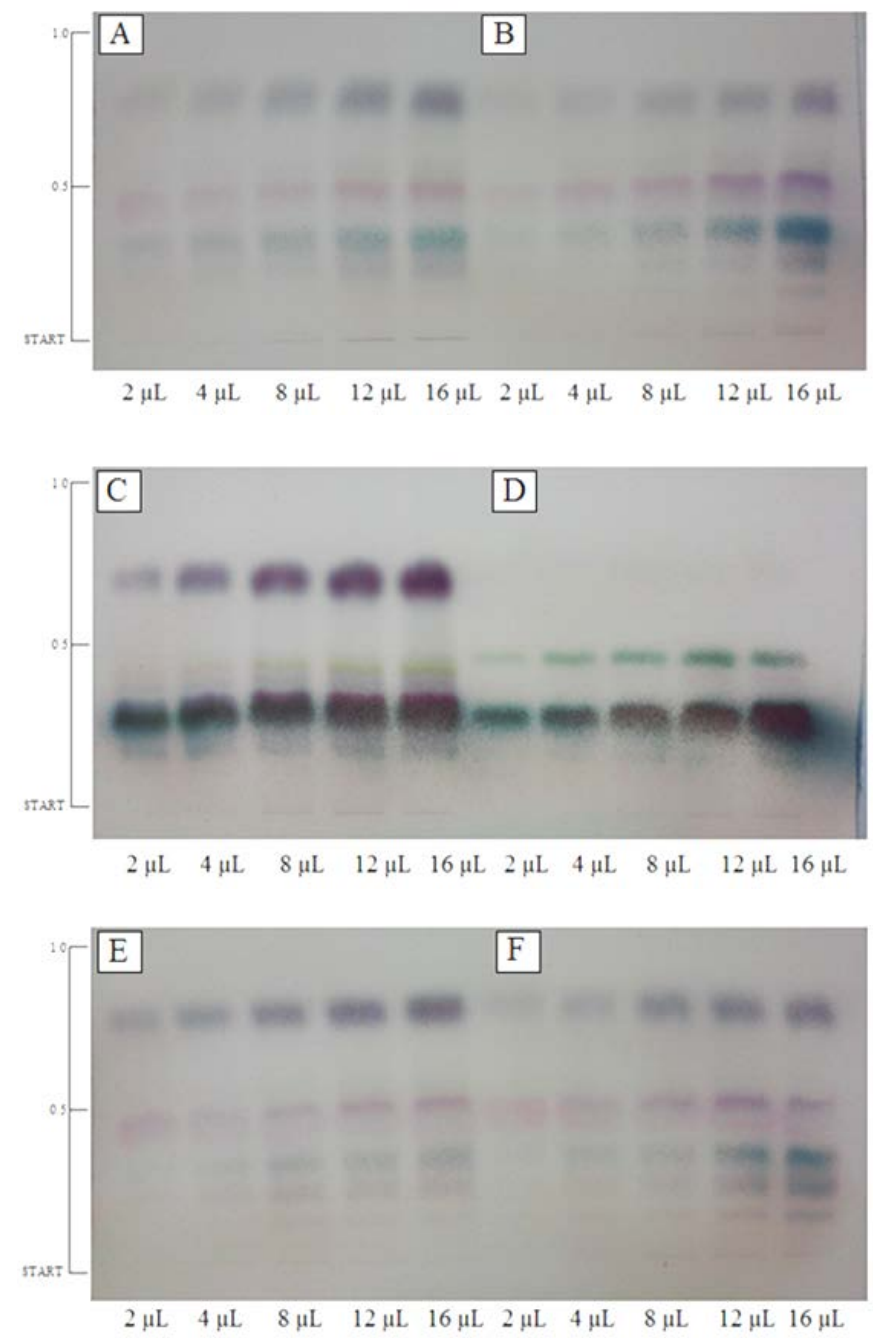

Fig 2. Identification TLC chromatograms of the Satureja montana $(A, B)$, Ocimum basilicum $(C, D)$ and Origanum

The classification of basil EOs is based on the content of linalool and methylchavicol (estragole), which are the two major components of the $O$. basilicum EO, resulting in four chemotypes: the chemotype $\mathrm{A}$ and the chemotype $\mathrm{B}$, with linalool and methylchavicol as the main component of the EO, respectively; the chemotype $A B$, the principal constituent of which is linalool, but with a relatively high content of methylchavicol; and the chemotype BA, which contains methylchavicol as the main constituent, followed by linalool (Baritaux et al., 1992). As linalool was the predominant compound in the basil EO obtained in this work (67.71\%), the sample belongs to the chemotype A. The basil EO obtained was rich in sesquiterpenes, i.e. $\beta$-elemene $(3.45 \%), \alpha$-bergamorene $(3.51 \%)$, farnesene $(1.40 \%), \gamma$-cadinene $(6.01 \%)$, caryophyllene oxide $(2.35 \%)$ and $\delta$-cadinene $(3.77 \%)$. A small portion of monoterpene hydrocarbons, i.e. $\beta$-pinene and myrcene $(0.60 \%$ and $1.17 \%$, respectively), was detected in basil EO obtained by HD. These compounds were not present in the O. basilicum EO obtained by MWHD, which emphasizes their possible oxidation. Binello et al. (2014) reported linalool degradation into $\alpha$ terpineol under microwave irradiation conditions. However, the $\alpha$-terpineol content in the basil EOs obtained by HD and MWHD was not significantly different $(1.62 \%$ and $1.50 \%$, respectively). The sesquiterpene content in the basil EO obtained by both techniques was very similar. Conversely, a decrease in the linalool content of the EO obtained by MWHD was followed by a significant increase in the thymol and eugenol content.

Carvacrol was the most dominant compound in the oregano EO obtained (93.42\%), as it was the case with winter savory. In addition to carvacrol, only its isomer, namely thymol, was present in a significant percentage (3.63\%), whereas the content of all other oxygenated monotepenes and sesquitepenes was less than $1 \%$. The most important qualitative characteristics of the oregano EO obtained by HD and MWHD were decreased carvacrol (68.08 \%) and increased linalool contents (19.36 \%) in the EO obtained by MWHD. Since the linalool content in the oregano EO obtained by HD was only $0.29 \%$, it is possible that microwave irradiation causes the decyclization of the phenol ring, the migration of the hydroxylic group and further formation of the linalool. Similar results were obtained by Binello et al. (2014) who reported a slight decrease in carvacrol in the oregano EO obtained by HD, followed by a slight increase in linalool.

There is a growing interest in the utilization of natural antioxidants because commonly used synthetic antioxidants (namely butylated hydroxytoluene, butylated hydroxyanisole, propyl galate and tertiary butyl hydroquinone) have been suspected to cause or promote negative health effects (Barlow, 1990). Aromatic plants and their products, such as extracts and EOs, have shown certain potential for the stabilization of various food products, e.g. biofilms with essential oils for food packaging (Hromiš et al., 2017). Radical scavenging activity expressed as the $\mathrm{IC}_{50}$ value of the EOs obtained by HD and MWHD is presented in Table 3. There is no significant difference between the antioxidant activities of the winter savory, basil and oregano EOs obtained by $\operatorname{HD}(0.0563,0.0550$ and $0.0542 \mathrm{mg} / \mathrm{mL}$, respectively), due to similar contents of antioxidant compounds. The EOs of basil and oregano obtained by HD exhibit a slightly higher antioxidant activity than the EO obtained by MWHD. Conversely, there is a significant increase in the antioxidant activity of the winter savory EO obtained by MWHD $(0.0289 \mathrm{mg} / \mathrm{mL})$. This could indicate that certain products of carvacrol degradation (Table 2) act as potent scavengers of DPPH radicals. According to Kulisic et al. (2004), the antioxidant activity of the oregano EO obtained by HD was $0.5 \mathrm{mg} / \mathrm{mL}$, which was a significantly lower activity than that of the oregano EO obtained in this study. On the other hand, the antioxidant activity of the basil EO obtained by HD (0.0542 $\mathrm{mg} / \mathrm{mL}$ ), which was a significantly lower activity than that of the basil EO obtained by Hussain et al. (2008) (approximately 0.005 $\mathrm{mg} / \mathrm{mL}$ ). However, variations in the results reported could be attributed to, first and foremost, different qualitative and quantitative compositions of EOs, as well as to different cultivars, origin, geographical growing location, cultivation, harvest handling and storage conditions of the plant material. 
Pavlić, Branimir et al./ Comp. Analysis of the Essen. Oils of Three Lamiaceae Species Obtai. by Conven. and Microwave-Assi. Hydr.

Table 2. Relative percentage of compounds identified in the essential oils investigated

\begin{tabular}{|c|c|c|c|c|c|c|c|}
\hline \multirow{3}{*}{ Compound } & \multirow{3}{*}{$\mathbf{t}_{\mathrm{R}}^{\mathrm{a}}[\mathrm{min}]$} & \multicolumn{6}{|c|}{ "Relative percentage [\%] } \\
\hline & & \multicolumn{2}{|c|}{ Satureja montana } & \multicolumn{2}{|c|}{ Ocimum basilicum } & \multicolumn{2}{|c|}{ Origanum vulgare } \\
\hline & & HD & MWHD & HD & MWHD & HD & MWHD \\
\hline p-Cymene & 13.39 & 0.38 & 0.42 & - & - & 0.16 & 2.37 \\
\hline$\beta$-Pinene & 14.23 & - & - & 0.60 & - & - & - \\
\hline Myrcene & 14.39 & - & - & 1.17 & - & - & - \\
\hline Eucalyptol & 15.91 & 0.29 & 0.19 & - & - & - & - \\
\hline$\gamma$-Terpinene & 17.28 & 0.21 & 0.36 & - & - & 0.14 & 2.01 \\
\hline Linalool & 18.65 & 0.87 & 1.31 & 67.71 & 49.06 & 0.29 & 19.36 \\
\hline Borneol & 21.63 & 0.95 & 1.25 & - & - & 0.24 & 0.19 \\
\hline Terpinene-4-ol & 21.75 & 0.44 & - & - & - & 0.23 & 0.17 \\
\hline$\alpha$-Terpineol & 22.14 & 0.17 & 0.67 & 1.62 & 1.50 & 0.14 & - \\
\hline Thymoquinone & 23.94 & 0.36 & 0.45 & - & - & - & - \\
\hline Geraniol & 24.39 & - & - & 1.61 & 2.15 & 0.15 & 0.11 \\
\hline Bornyl acetate & 25.72 & - & - & - & 1.24 & - & - \\
\hline Thymol & 26.11 & 0.09 & 0.17 & 1.33 & 12.00 & 3.63 & 4.82 \\
\hline Carvacrol & 26.31 & 92.20 & 84.11 & - & - & 93.42 & 68.08 \\
\hline Eugenol & 28.37 & - & - & 5.46 & 17.42 & - & - \\
\hline n.i. ${ }^{b}$ & 28.45 & - & 7.29 & - & - & - & - \\
\hline$\alpha$-Cubebene & 29.08 & 0.14 & 0.25 & - & - & - & - \\
\hline$\beta$-Elemene & 31.62 & - & - & 3.45 & 3.07 & - & - \\
\hline trans-Caryophyllene & 33.64 & 0.81 & 0.43 & - & - & 0.75 & - \\
\hline$\alpha$-Bergamotene & 34.44 & - & - & 3.51 & 2.04 & - & - \\
\hline Farnesene & 34.70 & - & - & 1.40 & - & - & - \\
\hline cis- $\alpha$-Bisabolene & 35.91 & - & - & - & - & 0.07 & - \\
\hline trans- $\gamma$-Bisabolene & 35.99 & - & - & - & - & 0.02 & - \\
\hline$\gamma$-Cadinene & 37.91 & - & - & 6.01 & 5.58 & - & - \\
\hline Caryophyllene oxide & 39.92 & - & - & 2.35 & 2.05 & 0.76 & - \\
\hline$\delta$-Cadinene & 40.52 & - & - & 3.77 & 3.30 & - & - \\
\hline Butylhydroquinone & 41.20 & 0.92 & 1.75 & - & - & - & - \\
\hline \multicolumn{2}{|c|}{ Total peak area [\%] } & 97.83 & 98.65 & 99.99 & 99.41 & 100.00 & 97.11 \\
\hline
\end{tabular}

a retention time

${ }^{\mathrm{b}}$ not identified

Table 3. Antioxidant activity of the essential oils obtained by HD and MWHD

\begin{tabular}{|l|l|l||}
\hline \multirow{2}{*}{ Essential oil } & $\mathbf{I C}_{\mathbf{5 0}}[\mathbf{m g} / \mathbf{m L}]$ \\
\cline { 2 - 3 } & HD & MWHD \\
\hline Satureja montana & 0.0563 & 0.0289 \\
\hline Ocimum basilicum & 0.0550 & 0.0680 \\
\hline Origanum vulgare & 0.0542 & 0.0604 \\
\hline
\end{tabular}

\section{CONCLUSIONS}

Compared to hydrodistillation (HD), microwave-assisted hydrodistillation (MWHD) has been recently proposed as an alternative method for EO isolation, which could provide certain advantages relative to costs, time and quality of products. The results obtained in this study suggest that $10 \mathrm{~min}$ of microwave irradiation is not enough for a complete exhaustion of plant material. Therefore, in order to achieve higher yields of EO, MWHD should be prolonged. With regard to the chemical profile, slight alterations were recorded in the EOs obtained by MWHD, which are not necessarily negative. Moreover, differences in the EOs obtained by HD and MWHD could indicate possible chemical reactions which occur during microwave irradiation. Relative to the antioxidant activity, there were no significant differences between the basil and oregano EOs obtained, whereas the winter savory EO obtained by MWHD exhibited an approximately twofold higher antioxidant activity, indicating that more potent products could be obtained using microwave treatment. However, more comprehensive research should be conducted in order to provide detailed information about the use of MWHD in lieu of HD.

ACKNOWLEDGMENTS: The authors gratefully acknowledge the financial support of the Ministry of Education, Science and Technological Development of the Republic of Serbia (Project No. TR31013), and the Provincial Secretariat for Higher Education and Scientific Research of the Autonomous Province of Vojvodina (Project No. 114-451-2800/2016-05).

\section{REFERENCES}

Baritaux, O., Richard, H., Touche, J., Derbesy, M. (1992). Effects of drying and storage of herbs and spices on the essential oil. Part I. Basil, Ocimum basilicum L. Flavour and Fragrance Journal, 7 (5), 267-271.

Barlow, S. M. (1990). Toxicological aspects of antioxidants used as food additives. In Food antioxidants (pp. 253-307). Springer Netherlands.

Binello, A., Orio, L., Pignata, G., Nicola, S., Chemat, F., Cravotto, G. (2014). Effect of microwaves on the in situ hydrodistillation of four different Lamiaceae. Comptes Rendus Chimie, 17 (3), 181-186.

Espín, J. C., Soler-Rivas, C., Wichers, H. J. (2000). Characterization of the total free radical scavenger capacity of vegetable oils and oil fractions using 2, 2-diphenyl-1picrylhydrazyl radical. Journal of Agricultural and Food Chemistry, 48 (3), 648-656. 
Feng, X., Jiang, Z. T., Wang, Y., Li, R. (2010). Composition Comparison of Essential Oils Extracted by Hydrodistillation and Microwave-assisted Hydrodistillation from Amomum tsao$k o$ in China. Journal of Essential Oil Bearing Plants, 13 (3), 286-291.

Filip, Snežana, Vidović, Senka, Adamović, D., Zeković, Z. (2014). Fractionation of non-polar compounds of basil (Ocimum basilicum L.) by supercritical fluid extraction (SFE). The Journal of Supercritical Fluids, 86, 85-90.

Golmakani, M. T., Rezaei, K. (2008). Comparison of microwave-assisted hydrodistillation with the traditional hydrodistillation method in the extraction of essential oils from Thymus vulgaris L. Food Chemistry, 109 (4), 925-930.

Golmakani, M. T., Rezaei, K. (2008). Microwave-assisted hydrodistillation of essential oil from Zataria multiflora Boiss. European Journal of Lipid Science and Technology, 110 (5), 448-454.

Hashemi-Moghaddam, H., Kalatejari, A., Afshari, H., Ebadi, A. G. (2013). Microwave Accelerated Distillation of Essential Oils from the Leaves of Eucalyptus microtheca: Optimization and Comparison with Conventional Hydrodistillation. Asian Journal of Chemistry, 25 (10), 5423-5427.

Hromiš, Nevena, Lazić, Vera, Bulut, Sanda, Popović, Senka, Šuput, Danijela, Markov, S. Džinić, Natalija, Tomović, V. (2017). Antimicrobial activity of composite chitosan biofilms with beeswax and caraway essential oil. Journal on Processing and Energy in Agriculture, 21 (2), 76-80.

Hussain, A. I., Anwar, F., Sherazi, S. T. H., Przybylski, R. (2008). Chemical composition, antioxidant and antimicrobial activities of basil (Ocimum basilicum) essential oils depends on seasonal variations. Food Chemistry, 108 (3), 986-995.

Jiang, Z. T., Feng, X., Li, R., Wang, Y. (2013). Composition Comparison of Essential Oils Extracted by Classical Hydro distillation and Microwave-assisted Hydrodistillation from Pimenta dioica. Journal of Essential Oil Bearing Plants, 16 (1), 45-50.

Kulisic, T., Radonic, A., Katalinic, V., Milos, M. (2004). Use of different methods for testing antioxidative activity of oregano essential oil. Food Chemistry, 85 (4), 633-640.

Milos, M., Radonic, A., Bezic, N., Dunkic, V. (2001). Localities and seasonal variations in the chemical composition of essential oils of Satureja montana L. and S. cuneifolia Ten. Flavour and Fragrance Journal, 16 (3), 157-160.

Mohamadi, M., Shamspur, T., Mostafavi, A. (2013). Comparison of microwave-assisted distillation and conventional hydrodistillation in the essential oil extraction of flowers Rosa damascena Mill. Journal of Essential Oil Research, 25 (1), 55-61.

Nikolić, T., Rešetnik, I. (2007). Plant uses in Croatia. Phytologia Balcanica, 13 (2), 229-238.

Panizzi, L., Flamini, G., Cioni, P. L., Morelli, I. (1993). Composition and antimicrobial properties of essential oils of four Mediterranean Lamiaceae. Journal of Ethnopharmacology, 39 (3), 167-170.

Pharmacopoea Jugoslavica, Editio Quarta (Ph. Jug. IV), vol. 1, Federal Institute of Public Health, Belgrade, Yugoslavia, 1984 (in Serbian).

Pourmortazavi, S. M., Hajimirsadeghi, S. S. (2007). Supercritical fluid extraction in plant essential and volatile oil analysis. Journal of Chromatography A, 1163 (1), 2-24.

Reverchon, E. (1997). Supercritical fluid extraction and fractionation of essential oils and related products. The Journal of Supercritical Fluids, 10 (1), 1-37.

Štefan, M. B., Rodríguez, J. V., Blažeković, B., Kindl, M., Vladimir-Knežević, S. (2014). Total hydroxycinnamic acids assay: Prevalidation and application on Lamiaceae species. Food Analytical Methods, 7 (2), 326-336.

Wagner, H., Bladt, S., Zgainski, E. M. (1984). Plant Drug Analysis Springer-Verlag. Berlin, Germany.

Wang, H., Liu, Y., Wei, S., Yan, Z. (2012). Comparative seasonal variation and chemical composition of essential oils from the leaves and stems of Schefflera heptaphylla using microwave-assisted and conventional hydrodistillation. Industrial Crops and Products, 36 (1), 229-237.

Wang, Y., Jiang, Z. T., Li, R. (2009). Composition Comparison of Essential Oils Extracted by Hydrodistillation and Microwave-assisted Hydrodistillation from Black Pepper (Piper nigrum L.) Grown in China. Journal of Essential Oil Bearing Plants, 12 (3), 374-380.

Received: 12. 10. 2018.

Accepted: 28. 11. 2018. 